\title{
Phenomenological structuralism: a structurationist theory of human action
}

\begin{abstract}
Building on Structurationist sociology, this work explores Paul C. Mocombe's synthesis of phenomenology and structural Marxism, phenomenological structuralism, as an essay in Structurationist theory and the phenomenological ontology of Edmund Husserl, Martin Heidegger, Maurice Merleau-Ponty, and Jean-Paul Sartre in order to resolve the structure/agency problematic of the social sciences.
\end{abstract}

Keywords: structuration theory, phenomenological structuralism, structure/agency, mythopraxis, quantum mechanics, social class language game
Volume I Issue I - 2017

\author{
Paul C Mocombe \\ Department of Sociology \& Philosophy, West Virginia State \\ University, USA
}

\author{
Correspondence: Paul C Mocombe,West Virginia State \\ University, The Mocombeian Foundation Inc, USA,
}

Email pmocombe@mocombeian.com

Received: April 26, 2017| Published: June 29, 2017

\section{Introduction}

Since the 1960 's, with the advent of postmodern and post-structural theories into the theoretical discourses of social science academics, a struggle regarding the origins and nature of identity, consciousness, and human action has dominated social science and philosophical theories. The issue centers on several factors raised by postmodern and post-structural thinkers in the likes of Michel Foucault, Jacques Derrida, and Jacques Lacan against the structuralism of the sciences

i. They question the validity regarding the Cartesian rational individual, which Foucault and Derrida deny in favor of their attempt to dissolve the subject altogether

ii. They question the interdependency of the constitution of a stable structure and a distinct subject with agency, in denying the latter they undermine the former

iii. They question the status of science

iv. Finally, they question the possibility of the objectivity of any language of description or analysis.

Although these factors raised in the writings of Jacques Lacan, Jacques Derrida, and Michel Foucault are theoretically legitimate and have posed tremendous problems for the social sciences and their constitution as a science based on the notion of a stable structure constituted by stable rational subjects with agency. These problems have not adequately been addressed by Marxist social theorists in the likes of working to resolve these issues, via the structure/agency problematic of the social sciences, by attempting to synthesize the phenomenological discourses of the former theorists with Marxist and structural Marxist philosophy. ${ }^{1-16}$ In this work, in building on the Structurationist responses of Althusser, Bourdieu, Habermas, Giddens, etc., I offer an alternative reading in phenomenological ontology and structuralism, which holds on to the individual, structure, and the notion of the indeterminacy of meaning or decentered subject of postmodernism and post-structuralism to resolve what is commonly referred to as the structure/agency problematic of the social sciences. To do so, I attempt to synthesize phenomenology, with structuralism in general, i.e., phenomenological structuralism, and structural Marxism in particular, via physics, and the Wittgenstein ${ }^{17}$ notion of "language games." In the end, my phenomenological structural (material) ontology seeks to resolve the structure/agency debate of the social sciences by highlighting the origins and nature of consciousness, identity, and human action through a synthesis of quantum mechanics, phenomenology, structural Marxism, and Wittgenstein's notion of Language games. ${ }^{17}$

\section{Background of the problem}

The Structurationist or praxis school in the social sciences is commonly associated with ${ }^{3-9}$ in sociology, and ${ }^{10-16}$ in anthropology. ${ }^{18,19}$ Elaborated in a series of theoretical works and empirical studies, Structurationist or praxis theorists account for agency and consciousness in social structure or system, "by clamping action and structure together in a notion of 'practice' or 'practices"'. ${ }^{18}$ That is, structures are not only external to social actors, as in the classic structural functional view, but are also internal rules and resources produced and reproduced by actors "unconsciously" (intuitively) in their practices. That is to say, in Structurationist or praxis theory, as Marx one-hundred years before suggested, the structure is "not a substantially separable order of reality", but "simply the 'ideal' form in which the totality of "material' relations are manifested to consciousness" From this perspective, accordingly, structure or, sociological speaking, social structure, "may set [(ideological)] conditions to the historical process, but it is dissolved and reformulated in material practice [(through mode of production and ideological apparatuses)], so that history becomes the realization, in the form of society, of the actual [(embodied rules)] resources people put into play": ${ }^{10-16}$ consciousness, as a result, refers to "practical consciousness" or the dissolution and reformulation of a social structure's terms (norms, values, prescriptions, and proscriptions) in material practice.

Although this Neo-Marxist "clamping together" of structure, praxis, and consciousness descriptively accounts for "the individual moment of phenomenology" by explaining the unanimity, closure, and "intentionality" of a form of human action or sociation, the capitalist social (material) relations of production and its class division, which constitutes the integrative actions of modern society, it fails, however, as pointed out in the epistemological postmodern/ post-structural positions of Foucault, Derrida, Lacan, hooks, and Collins, to account for the origins and nature of fully visible alternative forms of practices (i.e., "the variability of the individual moments of phenomenology") within the dominant order that are not class based, but are the product of the deferment of meaning in ego- 
centered communicative discourse. Structurationist fail to see that society and its dominant institutionalized identity is not solely "onedimensional" and differentiated by the dialectic of capitalist social relations of production, but is constituted, through power relations, as transition, relation, and difference. This difference, akin to Jacques Derrida's différance, is not biologically (racially) hardwired in the social actor, but is a result of self-reflective and non-impulsive social actors, upon internalizing the arbitrary structural terms or signifiers of their society via their consciousness, bodies, language, and linguistic communication, conceiving of and exercising other forms of beingin-the-world from that of the dominant symbolic order and its structural differentiation or relational logic..$^{6-9}$

By "clamping" action, structure, and consciousness together, i.e., part/whole totality, however, Structurationist do not account for, nor demonstrate, the nature and relation of this non-biologically and nonimpulsive determined difference (différance) to that of the dominant practices of the social structure as highlighted in the theorizing of postmodern and post-structural scholars. Instead, they re-introduce the problem in a new form: How do we know or exercise anything at odds with an embodied received view grounded in, and differentiated by, capitalist social relations of production? My phenomenological structural ontology seeks to fix structurationism to account for this problematic.

\section{Theory}

In essence, the origins and nature of consciousness is fourfold. It is the stance of a transcendental ego vis-à-vis

a) The drives of the aggregated body and brain

b) The drives or impulses of recycled subatomic particles

c) Structural reproduction and differentiation of ideologies, ideological apparatuses, and mode of production and

d) The deferment of meaning in ego-centered communicative discourse, which determines human practical consciousness.

In other words, what I am suggesting here in my phenomenological structuralism, which seeks to highlight the phenomenology of beingin-the-structure-of-those-who-control-a-material-resourceframework and the origins of our practical consciousness, is that embodiment is the objectification of the transcendental ego, which is a part of an universal élan vital (Henri Bergson's term), the primeval pan-psychic field, that has ontological status in dimensions existing at the subatomic particle level and gets embodied via, and as, the body and connectum of Being's brains. Hence the transcendental ego is the universal élan vital, which is the neuronal energies of past, present, and future Beings-of-the-multiverse, embodied. This transcendental ego, and its stance, encounters a material world via and as the body and brain in mode of production, language, ideology, ideological apparatuses, and communicative discourses.

Once embodied in and as human individual consciousnesses in a particular universe, world, and historical social formation, the transcendental ego becomes an embodied hermeneutic structure that never encounters the world and the things of the world in themselves via the aggregated built-in genetic ontology of the body and the impulses or phenomenal properties of the neuronal energies. Instead embodied hermeneutic individual consciousness is constituted via the recycled subatomic neuronal particle energies which are aggregated as a transcendental ego and the body in their encounter and interpretation of past recycled neuronal memories and things enframed in and by the language, bodies, ideology, ideological apparatuses, practices, and communicative discourses of those who control the economic conditions of a material resource framework and its social relations of production. In consciousness, as phenomenology posits, it (individual subjective consciousness of embodied beings) can either choose to accept the structural knowledge, differentiation, and practices of the body; the impulses or phenomenal properties of recycled past consciousnesses of subatomic neuronal particles; the ideologies of those who control, via the actions of their bodies, mode of production, language, ideology, ideological apparatuses, and communicative discourse, the economic conditions of the material resource framework and recursively reorganize and reproduce them in their practices; or reject them, given the ability to defer meaning in ego-centered communicative discourse, for an indeterminate amount of actiontheoretic ways-of-being-in-the-world-with-others, which they may assume at the threat to their ontological security. It is Being's stance, ready-to-hand, unready-to-hand, and present-at-hand vis-à-vis

I. The drives of the body

II. Impulses of residual actions/memories of embodied recycled past consciousnesses

III. The phenomenological meditation/deferment that occurs on the latter actions via linguistic communication, and

IV. Ideologies of a social system along with its differentiating logic, coupled with

$\mathrm{V}$. The will of those in power positions, which produces the variability of actions and practices in cultures, social structures, or social systems that enframe the material world.

As such, as in Heidegger's phenomenology, phenomenology in phenomenological structuralism is not just transcendental, it is also hermeneutical. The act of interpretation (based on the stance of being) or an embodied hermeneutic structure via the body, language, ideology, and communicative discourse is a universal precondition of being-inthe-world-with-other-human-beings. However, whereas Heidegger is interested in the question of the meaning of Being-as-such, i.e., the phenomenology of Being, phenomenological structuralism is concerned with the sociology of Being, the question of the meaning or constitutive nature of embodied Being-as-such-as-being-in-theworld-with-others who attempt to constrain practical consciousnesses via the actions of their bodies, language, ideologies, ideological apparatuses, and communicative discourse derived from social relations of the mode of production. That is, as in Martin Heidegger's phenomenological ontology, I am interested in the necessary societal aggregations, relationships, and practical consciousnesses that emerge out of the phenomenology of Being-in-the-world-within-structuresof-signification-of-others, who control the economic conditions of the material resource framework we find ourselves existing in, that presuppose our historicity, and Being's perceptions, responses, and practices, i.e., relations, to these structures-of-signification in order to be in the world. Unlike Heidegger, however, my concern is not with the phenomenology of being-in-the-world as such because being never encounters the world and its transcendental ego as the-thingitself. Instead being encounters the world via its body/brain, recycled (impulses of) past consciousnesses, and structures of signification (social class language), which derive from class division and social relations of production as reified in the bodies (as agential initiative), language, ideology, ideological apparatuses, and communicative 
discourse of those who control the resources (and their distribution, i.e., mode of production) of a material resource framework.

Be that as it may, whereas I accept the Husserlian phenomenological understanding that the facts of the world and their conditions of possibility are present in consciousness, i.e., the notion of intentionality, consciousness is always consciousness of something as we experience being-in-the-world-with-other-beings via our consciousness, i.e., transcendental ego, bodies, language, ideologies, and communicative discourse. My position here, however, is that as an embodied hermeneutic structured being we never experience the facts of the world and their conditions of possibility as the "the things in themselves." We experience them not culturally and historically, which is a present-at-hand viewpoint, but structurally and relationally (the structure of the conjuncture as determined by the social relations of the mode of production), via the bodies, language, ideology, and communicative discourse in institutions or ideological apparatuses, i.e., the social class language game, of those who control the economic conditions of the material resource framework we find ourselves thrown-in, via our bodies, language, and communicative discourse.

In other words, my phenomenology of embodied Being-inthe-world-as-such-as-Being-with-others, phenomenological structuralism, synthesizes Merleau-Ponty's and Heidegger's phenomenology with Karl Marx's materialism and Ludwig Wittgenstein's language game to suggest that being-in-theworld with others, our practical consciousness, is a product of our interpretation, acceptance, or rejection of the symbols of signification, social class language game, of those bodies in institutional/ideological power positions who control via their bodies, language, ideologies, ideological apparatuses, and communicative discourse the economic conditions of a material resource framework as we encounter them and their symbols/signifiers in institutions or ideological apparatuses via our own transcendental ego, bodies, language, and communicative discourse. Hence we never experience the things-in-themselves of the world culturally and historically in consciousness. We experience them structurally or relationally, and our stances, ready-to-hand, unready-to-hand, present-at-hand, vis-à-vis these ideological structures determine our practical consciousness or behaviors.

We initially know, experience, and utilize the things of the world in the preontological ready-to-hand mode, which is structural and relational. That is, our bodies and impulses encounter, know, experience, and utilize the things of the world in consciousness, inter subjectively, via their representation as objects of knowledge, truth, usage, and experience enframed and defined in the relational logic and practices or language game (Wittgenstein's term) of the institutions or ideological apparatuses of the other beings-of-thematerial resource framework whose historicity comes before our own and gets reified in and as language, ideology, ideological apparatuses, and communicative discourse based on their mode of production or satisfying the needs of the aggregated body. This is the predefined phenomenal structural, i.e., ontological, world we, the psychion or transcendental ego of the primeval pan-psychic field, and our bodies are thrown-in in coming to be-in-the-world. How an embodiedhermeneutically-structured Being as such solipsistically goes on to view, experience, understand, and utilize the predefined objects of knowledge, truth, and experienced defined by others and their conditions of possibilities in consciousness in order to formulate their practical consciousness is albeit indeterminate. Heidegger is accurate, however, in suggesting that three stances or modes of encounter (Analytic of Dasein), "presence-at-hand," "readiness-tohand," and "un-readiness-to-hand," characterizes our views of the things of consciousness represented inter subjectively via bodies, language, ideology, and communicative discourse, and subsequently determine our practical consciousness or social agency. In "ready-tohand," which is the preontological mode of human existence thrown in the world, we accept and use the things in consciousness with no conscious experience of them, i.e., without thinking about them or giving them any meaning or signification outside of their intended usage. Heidegger's example is that of using a hammer in hammering. We use a hammer without thinking about it or giving it any other condition of possibility outside of its intended usage as defined by those whose historicity presupposes our own. In "present-at-hand," which, according to Heidegger, is the stance of science, we objectify the things of consciousness and attempt to determine and reify their meanings, usage, and conditions of possibilities. Hence the hammer is intended for hammering by those who created it as a thing solely meant as such. The "unready-to-hand" outlook is assumed when something goes wrong in our usage of a thing of consciousness as defined and determined by those who adopt a "present-at-hand" view. As in the case of the hammer, the unready-to-hand view is assumed when the hammer breaks and we have to objectify it, by then assuming a present-at-hand position, and think about it in order to either reconstitute it as a hammer, or give it another condition of possibility. Any other condition of possibility that we give the hammer outside of its initial condition of possibility which presupposed our historicity becomes relational, defined in relation to any of its other conditions of possibilities it may have been given by others we exist in the world with. Hence for Heidegger, the ontological status of being-in-theworld-with-others, via these three stances or modes of encountering the objects of consciousness hermeneutically reveal, through our view, experience, understanding, and usage of the predefined objects of knowledge, truth, and experience. Whereas Heidegger in his phenomenological work goes on to deal with the existential themes of anxiety, alienation, death, despair, etc. in my phenomenological stance regarding societal constitution or Beings-as-such's-being-in-theworld-with-others via our stances to the body, language, ideology, ideological apparatuses, communicative discourse, and social relations of production I am not concerned with the phenomenological preoccupation of individual solipsistic existence as defined in JeanPaul Sartre's work which claims to take off from Heidegger. Instead, I am interested in the universal ontological structure, i.e., social structure or societal constitution and practical consciousness, which arises out of Heidegger's three stances, what I am calling phenomenological structuralism, vis-à-vis embodiment, language, ideology, ideological apparatuses, communicative discourse, and social relations of the mode of production. That is, I am not concerned with Sartre's phenomenologization of the Cartesian res cogitans/transcendental ego, i.e., the present-at-hand transcendental ego, which he gives ontological status in the world as a solipsistic individual seeking to define themselves for themselves lest they be declared living in bad faith. In my view, the overemphasis of that particular aspect of Dasein is a product of a specific historical and relational mode of production, and only account for one of its analytics as highlighted by Heidegger. For me, the transcendental ego, which is a part of a universal élan vital, the primeval pan-psychic field, existing in another dimension at the subatomic particle level, does not originate out of the historical material world, but several variations of it becomes objectified via embodiment and the aforementioned stances in a universe, galaxy, 
and historical material world structured by other embodied Beings and their stances. Upon death its historicity via subatomic neuronal particles gets reabsorbed into the élan vital, primeval pan-psychic field, to be recycled to produce future beings. As such consciousness, i.e., practical consciousness, is a product of the stances of Dasein vis-à-vis its embodied recycled past consciousnesses/impulses, phenomenal properties, language, and ideology, which can be deferred in ego-centered communicative discourse, and structural reproduction and differentiation determined by mode of production, ideological apparatuses, and those in power positions. Be that as it may, as with Heidegger, who refutes Sartre's existential rendering of his phenomenological ontology, I am interested in the objectified/ reified societal constitution and practical consciousnesses of the transcendental egos and their relations that emerge within a dominant constitution of Being that controls a material resource framework of the world via bodies, mode of production, language, ideology, ideological apparatuses, and communicative discourse vis-à-vis the stances of the transcendental ego.

Hence the understanding here is that the transcendental ego of Being becomes embodied and objectified in a material resource framework enframed by the actions of bodies, the mode of production, language, ideology, ideological apparatuses, and communicative discourse of those who control the resources of the framework. As embodied consciousness the transcendental ego initially encounters itself and the world in the ready-to-hand preontological mode. This means as aggregated recycled subatomic particle, being is, initially, unconsciously driven by the drives of its body and the agential initiatives or impulses (phenomenal properties) of recycled past subatomic neuronal particles as limited by their embodiment. If its drives or impulses are uninhibited by the bodies, mode of production, language, ideology, ideological apparatuses, and communicative discourse, i.e., social class language game, of those who control the material resource framework, Being may spend all of their existence in this stance. However, should they encounter resistance vis-à-vis their drives and the social class language game of those who control the material resource framework, being moves to the unready-tohand stance where they think about and question their own drives and or those of the material resource framework. At which point, they may become present-at-hand and may opt for either the practices associated with their internal drive or impulses, which they reify as culture, or that of the social class language game in power. If they choose the latter, being simply seeks the structural practices and differentiation of power at the expense of their internal drive. In the former case, choosing to reproduce their internal drives, impulses, or deferred meaning of linguistic structures, being, attempts to recursively reproduce what was the unconscious drives of recycled past consciousnesses, the body, or deferred meaning in the conscious present-at-hand stance at the threat to their ontological security in the material resource framework. At which point they may seek other Beings who share their drives, impulses, deferred meaning, or seek to change the ideology of power to accept what has become a decentered subject who has deferred the meaning of power. The latter position is the basis for postmodern and post-structural thought, and alternative practices outside of structural reproduction and differentiation of the mode of production that constitutes a society.

\section{Discussion}

Phenomenological structuralism, therefore, seeks to highlight the ontological universal modes of embodied human existence with others, which relationally has emerged out of the phenomenological processes (Heidegger's three stances) of the transcendental ego experiencing, interpreting, and using the representational facts of its embodiment vis-à-vis the world as defined by and in the language game of others who control objects of a material resource framework, and how these modes of human existence come to (re) shape practical consciousness and constitute social structure or societal constitution.

Phenomenological structuralism posits consciousness to be the by-product or evolution of subatomic particles unfolding with increasing levels of abstraction within a material resource framework enframed by the mode of production, language, ideology, ideological apparatuses, and communicative discourse of bodies recursively reorganizing and reproducing the ideals of the latter factors as their practical consciousness. Subatomic particles, via the Higgs boson particle, gave rise to carbon atoms, molecules and chemistry, which gave rise to DNA, biological organisms, neurons and nervous systems, which aggregated into bodies and brains that gave rise to the preexisting consciousness of the subatomic particles, bodies, and languages. In human beings, the indeterminate behavior of subatomic neuronal energies that produced the plethora of consciousnesses and languages in the neocortex of the brain gave rise to ideologies, which in turn gave rise to ideological apparatuses and societies (sociology) under the social class language game or language, ideology, and ideological apparatuses of those who organize and control the material resources (and their distribution) required for physical (embodied) survival in a particular resource framework. So contrary to Karl Marx's materialism which posits human consciousness to be the product of material conditions, the logic here is a structural Marxist one in the Althusserian sense. That is, the aggregated, atomic, mature human being is a body and neuronal drives that never encounters the (ontological) material world directly. Instead, they encounter the (ideological) world via structures of signification, which structures the world or a particular part of it through the body, language, ideology, and ideological apparatuses, i.e., social class language game, of those whose power and power positions dictate how the resources of that framework are to be gathered, used, and distributed (means and mode of production).

Hence in the end, subject constitution is a product of an individual's stance, i.e., analytics, vis-à-vis three structures of signification and the ability to defer meaning in ego-centered communicative discourse stemming from the social class language game (i.e., language, symbols, ideology, ideological apparatuses, and communicative discourse) of those who control the mode of production of a material resource framework. It is the ready-to-hand drives of the body and brain, ready-to-hand and present-at-hand manifestation of past recycled residual consciousnesses/subatomic particles, the present-at-hand phenomenological meditation and deferment of meaning that occurs in embodied consciousness via language, ideology, and communicative discourse as reflected in diverse individual practices, within the readyto-hand, unready-to-hand, and present-at-hand differentiating logic or class divisions of the social relations of production, which produces the variability of actions and practices in cultures, social structures, or social systems. All four types of actions, the drives/impulses of the body and residual past consciousnesses of subatomic particles, structural reproduction/differentiation, and actions resulting from the deferment of meaning in ego-centered communicative discourse, are always present and manifested in a social structure (which is the reified ideology via ideological apparatuses, their social class language game, of those who control a material resource framework) 
to some degree contingent upon the will and desires of the economic social class that controls the material resource framework through the actions of their bodies (practical consciousness), language, symbols, ideology, ideological apparatuses, and social relations of production. They choose, amidst the class division of the social relations of production, what other meaning constitutions and practices are allowed to manifest themselves without the Beings of that practice facing alienation, marginalization, domination, or death.

The individual being is initially constituted as recycled and embodied subatomic particles of the multiverse, which have their own predetermined form of understanding and cognition, phenomenal properties, based on previous experiences as aggregated matter (this is akin to what the Greek philosopher Plato refers to when he posits knowledge as recollection of the Soul). Again, the individual's actions are not necessarily determined by the embodiment and drives of these recycled subatomic particles. It is an individual's stance, ready-tohand, unready-to-hand, and present-at-hand, when the subatomic particles become aggregated matter or embodied, which determines whether are not they become aware, present-at-hand, of the subatomic particle drives and choose to recursively reorganize and reproduce the content of the drives as their practical consciousness.

This desire to reproduce the cognition and understanding of the drives of the recycled subatomic particles, however, may be limited by the structuring structure of the aggregated body and brain of the individual subject. That is to say, the second origins and basis of an individual's actions are the structuring drives and desires, for food, clothing, shelter, social interaction, and sex, of the aggregated body and brain, which the subatomic particles constitute and embody. In other words, the aggregated body and brain is preprogrammed with its own (biological) forms of sensibility, understanding, and cognition, structuring structure, by which it experiences being-in-the-world as aggregated embodied subatomic particles. These bodily forms of sensibility, understanding, and cognition, such as the drive and desire for food, clothing, shelter, social interaction, linguistic communication, and sex, are tied to the material embodiment and survival of the embodied individual actor, and may or may not supersede or conflict with the desire and drive of an individual to recursively (re) organize and reproduce the structuring structure of the recycled subatomic particles. If these two initial structuring structures are in conflict, the individual moves from the ready-to-hand to the unready-to-hand stance or analytics where they may begin to reflect upon and question their being-in-the-world prior to acting. Hence just as in the case of the structuring structure of the subatomic particles it is an individual being's analytics vis-à-vis the drives of its body and brain in relation to the impulses of the subatomic particles, which determines whether or not they become driven by the desire to solely fulfill the material needs of their body and brain at the expense of the drives/desires of the subatomic particles or the social class language game of the material resource framework they find their existence unfolding in.

The social class language game, and its differentiating effects, an individual find their existence unfolding in is the third structuring structure, which attempts to determine the actions of individual beings as they experience being-in-the-world as embodied subatomic particles. The aggregated individual finds themselves objectified and unfolding within a material resource framework controlled by the actions of other bodies, which presuppose their existence, via the actions of their bodies (practical consciousness), language, communicative discourse, ideology, and ideological apparatuses stemming from how they satisfy the desires of their bodies and subatomic particle drives (means and mode of production). What is aggregated as a social class language game by those in power positions via and within its language, ideology, ideological apparatuses, and communicative discourse attempts to interpellate and subjectify other beings to its interpretive frame of satisfying their bodily needs, fulfilling the impulses of their subatomic particles, and organizing a material resource framework at the expense of all others, and becomes a third form of structuring individual action based on the mode of production and how it differentiates individual actors.

That is to say, an individual's interpellation, subjectification, and differentiation within the social class language game that presupposes their being-in-the-world attempts to determine their actions or practical consciousness via the reified language, ideology, etc., of the social class language game, the meaning of which can be deferred via the communicative discourse of the individual actors. Hence, the deferment of meaning in ego-centered communicative discourse of the language and ideology of a social class language game is the final means of determining an individual's action or practical consciousness outside of, and in relation to, its stance, i.e., analytics, vis-à-vis the drives of subatomic particles, drives and desires of the body and brain, and structural reproduction and differentiation.

Whereas the practical consciousness of the transcendental ego stemming from the impulses of embodied subatomic particles are indeterminant as with its neuronal processes involved with the constitution of meaning in ego-centered communicative discourse (Albeit physicists are in the process of exploring the nature, origins, and final states of subatomic particles, and neuroscientists are attempting to understand the role of neuronal activities in developing the transcendental ego and whether or not it continues to exist after death). The form of the understandings and sensibilities of the body and brain are determinant as with structural reproduction and differentiation of the mode of production, and therefore can be mapped out by neuroscientists, biologists, and sociologists to determine the nature, origins, and directions of societal constitution and an individual actor's practical consciousness.

The interaction of all four elements in relation to the stance of the transcendental ego of the individual actor is the basis for human action in the world. However, in the end, consequently, the majority of practical consciousness will be a product of an individual actor's embodiment and the structural reproduction and differentiation of a social class language game given

a. The determinant nature of embodiment, form of understanding and sensibility of the body and brain amidst, paradoxically, the indeterminacy of impulses of embodied subatomic particles and the neuronal processes involved in ego-centered communicative discourse.

b. The consolidation of power of those who control the material resource framework wherein a society, the social class language game, is ensconced and the threat that power (consolidated and constituted via the actions of bodies, mode of production, language, ideology, ideological apparatuses, and communicative discourse) poses to the ontological security of an aggregated individual actor who chooses (or not) either ready-to-hand or present-at-hand to recursively reorganize and reproduce the ideals of the society as their practical consciousness. It should also be mentioned that in response to this latter process, those 
in power positions who internalize the ideals of the social structure and recursively (re) organize and reproduce them as their practical consciousness are in the unready-to-hand when they encounter alternative forms of being-in-the-world within their social class language game. They dialectically attempt to reconcile the practical consciousness of their social class language game with the reified practical consciousness of those who have deferred their meanings for alternative forms of being-in-the-world within their social class language. They can accept, marginalize, or seek to eradicate the deferred or decentered subject or their practices.

\section{Phenomenological structuralism diagrammatically}

Hence phenomenological structuralism agrees with the structurationists that in the constitution of society the individual elements incorporate the structure of the ideological whole and gets differentiated by the relational logic of that whole. My understanding, unlike that of the traditional structurationists, attempts to provide an analytical tool to explain and examine the relation of the "others" within the totality who do not, however: the relationship between "the individual elements [who,] internalize [and recursively reproduce], [the structuring ideology] of the whole," and those who as a result of their ready-to-hand, unready-to-hand, and present-at-hand stances vis-à-vis the drives of their bodies, residual past consciousnesses of recycled subatomic particles or through self- reflection or phenomenological meditation in the unready-to-hand and presentat-hand mode of encountering the structural terms of a society conceive of, or choose among, fully visible "alternative" ways of being-in-the-world, which they attempt to exercise in the "totality."

This "mechanical" relationship can be expressed diagrammatically (Figure 1), and is an adaptation of description of colonialism's multiple strategies for regulating Europe's others and the way I see it, whether in my usage of it or slightly different depiction, it is a macro, at the societal level, extrapolation of Hegel's and Marx's master/slave dialectical power model, which would proceed along line A1, since we both suppose that our respective concepts (colonialism and the ideology of a society, culture, structure, what have you, emanating from the social relations of the mode of production, for me) are ideological or discursive formations constituted through power relations.

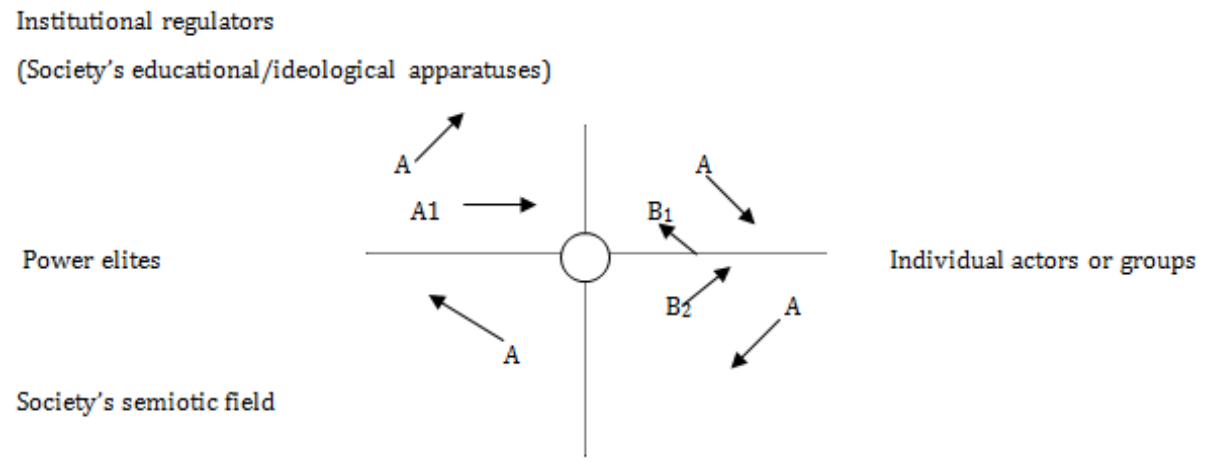

Figure I Diagram representing the nature of the relationship between society and the individual or group in phenomenological structuralism. " $A$ " represent the power elites of the social structure; $B_{1}$ represent those "others" (hybrids) with their gaze upon the eye of power seeking to be like " $A$ "; $B_{2}$ represent those with their gaze averted from the eye of power seeking to exercise an alternative practical consciousness from that of "As" and "B, s."

The general understanding, within a phenomenological structural understanding of the constitution of society and practical consciousness, is that individual actors or network of solidarity or cultural groups (irreducibly "mediating" situated subjects), represented by lines " $\mathrm{A}$ " and "B" on the diagram, are relationally socialized within society-its semiotic field or predefined and predetermined lexicons and representations of signification (at the bottom of the diagram) i.e., the field of socialization "and its investment in reproducing and naturalizing the structures of power" through "ideological apparatuses" (at the top of the diagram) controlled by socialized institutional regulators ("As"), power elites or those in power positions, who recursively reorganize and reproduce the rules of conduct (which appear to be natural and commonsensical) of the social structure, which in modern times represent an ideological flanking for the protestant/capitalist economic subjugation running along line "A1." Where in the first instance (A) there is encountering of the rules of conduct of the society at the preontological ready-tohand mode of encountering, there is adoption or internalization (the Structurationist view) on behalf of the individual or network of groups of the prescribed understanding of the representations and practices of the semiotic field, i.e., the recursively organized and reproduced rules of conduct which are sanctioned. In the second (B), the individual encounters the facts and values of the world in either unready-to-hand or the present-at-hand mode, and through a form of phenomenological meditation on the structural terms (i.e., norms, values, prescriptions and proscriptions of power) that presuppose their existence, conceives of, or chooses among other or fully visible alternatives (other "Bs" discriminated by the social structure), a different understanding (, i.e., practical means, arriving from the drives of the body, unconscious drives of recycled subatomic particles, or through the deferment of meaning in ego-centered communicative discourse) of being-in-theworld; or as in the case of racism, sexism, and classism is prescribed a structurally differentiated unalterable subordinate role based on the relational binary logic (rules for inclusion and exclusion) of the semiotic field of those in power positions ("As"). In this structurally differentiated mode the encountering is always either at the ready-tohand or unready-to-hand mode of encountering, in the latter because something, discriminatory effects of the totality, is wrong in allowing the social actor to partake in the rules of conduct of the society. So regardless if they accept or reject the rules of conduct, they are still classified by the power elites as (Bs).

The socialized individuals or groups ("As")-socialized in the "constitutive power of societal apparatuses like the church, education, etc., and the constitutive power of fields of knowledge [which stems from the semiotic field] within those apparatuses" (46)-possess the 
potential to become, if they so choose, power elites and as such institutional regulators (at the top of the diagram), who subordinate through the manufacture of consent. Now to maintain power, those who become regulators (some "As") must address "B's" signification, which relationally undermines (it gives social actors an "alternative" form of being-in-the-world), as well as define, delimits, and stabilizes the predefined lexicons and representations of signification that is the society's semiotic field. In other words, their ("Bs"") interpretations or structurally differentiated identity in relation to "A's" reject the singularity and realism or naturalism attached to the representations and meanings of the social field, while at the same time helping to constitute it by defining, delimiting, and stabilizing the field, i.e., "B's" interpretation in relation to "A's" helps to define, because it is not, "A's" interpretation. Hence, the "As" must negotiate, appropriate, and re-inflect "Bs" interpretive-practices into the semiotic field in order to delimit, their own; this is done, or has been done, up to this point in the human archaeological records on the constitution of society, by having them ("Bs") remain outside the field, by dismissing their interpretive-claims, in which case the field justifies their permanent outsider status (oppressed or discriminated against minorities, i.e., marginalized "other").

The "Bs," for the most part, can either accept (if their gaze is upon the eye of power-"As"-for recognition as a structurally differentiated "other," i.e., a class-in-itself) their appropriation, the rationale the institutional regulators ("As") prescribe to their ("B s"”) interpretivepractical consciousness which legitimates it as a representation, or they (" $\mathrm{B}_{2}$ ") may choose (by averting their gaze as a class-foritself) to remain quasi-outsiders if the meaning disclosed by the dominant institutional regulators is not in accordance with their own, or a previously discriminated subculture's, interpretive-practical understanding of the signifiers of the social structure. Regardless of what choice they ("Bs") make, however, they, "Bs," because the validity claims the institutional regulators provide for their (Bs') understanding validates their existence to start with, constantly attempt incorporation and acceptance, either, as a "class-in-itself," pushing for integration as a structurally differentiated "other" (hybrid) who recursively reproduce the rules of conduct of the social structure (" $\mathrm{B}_{1} \mathrm{~s}$ ")); or separation (" $\mathrm{B}_{2} \mathrm{~s}$ "), as a "class-for-itself," for their own rules of conduct which are sanctioned by the power elites of the subculture. The former is the position of the bourgeoisie's of once discriminated against groups, such as blacks, women, etc., in contemporary postindustrial Protestant capitalist societies seeking to partake as a hybrid other in the social class language games of the society.

Thus there are two fundamental paths which are open to "Bs": first, if they (B) accept the understanding of (A), regarding their interpretation as an "other," and seek integration, as a structurally differentiated "class-in-itself," they have to give up their interpretivepractical consciousness, which on the one hand undermines the legitimation of the interpretive community they are classed with, while on the other hand, legitimating society's semiotic field, which has appropriated their ("Bs"”) understanding and representation to substantiate and delimit their (As') power position and "practical consciousness." From this perspective, the "Bs," "B $\mathrm{B}_{1} \mathrm{~s}$ ", who accept appropriation, are socialized (institutionalized) and attempt to live as ("As"), which entail recursively organizing and reproducing, as a hybrid "other," the rules of conduct of the society which are sanctioned. Those who do not (the second path), that is, those in the present-at-hand mode of encountering who reject the rules of conduct of the society, for their own, " $\mathrm{B}_{2} \mathrm{~s}$ ", , may seek to reconstitute society in line with their interpretive-practical consciousness, which gives rise to another (warring) structure of signification or form of being-inthe-world, which, as a segregated categorical boundary or alternative practical consciousness, relationally and differentially delimits that of the society or social structure, which they initially constituted.

From the perspective of power, "As," "Bs"” interpretations, their interpretive-practical consciousness, are always represented in the semiotic field in order to define, delimit, and stabilize the power structure. Thus, "Bs" are always oppressed minorities or majorities, i.e., "others," in the Hegelian master/slave relationship (A1), who must construct their identities or consciousness within two or more ideals: that of the social structure (master's own understanding of themselves) and what it says of the discriminated against "other" (the slave). Hence, the "Bs," as long as their gaze is turned back upon the eyes of power (vector of motion of " $\mathrm{B}_{1} \mathrm{~s}$ ") for recognition in the unready-to-hand mode of encountering, which seeks to fix the status quo for their participation, pose no real danger to the semiotic field, unless following the aforementioned second path, " $\mathrm{B}_{2} \mathrm{~s}$,",-they should take-up arms against it as a distinct structuring structure, i.e., "classfor-itself" or categorical boundary, which has averted their gaze, and are attempting to preserve or universalize their "alternative" ontology or "practical consciousness." This latter position is represented by Islamic fundamentalists contemporarily, and the African participants of Bois Caiman during the Haitian Revolution.

In other words, in having to construct their (Bs) identities or consciousness by warring against the ideals of the social structure, which become the relational terms that defines, delimits, and stabilizes the social structure and that by which all ("As" and "Bs") must construct their consciousness, the gaze back upon the eye of power is a sign of recognition of the validity claims of the social structure, which necessarily implies that in order to be recognized the "Bs" must attempt to be what they are not, like "As." This agential move to be like "As," however, constrains the variability of practices, which, as the diagram highlights, can only be maintained if the gaze of Bs' (vector of motion of "B $\mathrm{B}_{2} \mathrm{~s}$ ") are averted away from the eyes of power in order to establish another segregated structuring structure, which celebrates and reproduces the practices' of their "otherness." So long as the aim of " $\mathrm{B}$ " is for acceptance into the structure of social relations that constitute the society, their "otherness" can only be expressed as those ("As") who recursively reorganize and reproduce the rules of conduct of the social structure. For it is only upon the world of existing state of affairs, i.e., the valid norms and subjective experiences of power, which is taken to be the nature of reality and existence as such, will they ("Bs") be admitted into the structure of social relations that constitute the society, for any other form may undermine the whole of social relations that is the constituted society.

\section{The role of power in the diagram}

Whereas, Figure 1 demonstrates the action of individual social actors or groups within "a" reified consciousness, social class language game, that forms the structure of relations that is their society, Figure 2 makes evident the actions of social actors (As), if and when, they become institutional/ideological regulators or power elites. The understanding here is that it is the legal regulations of a society, its "lexicons and representations of signification," its rules of conduct that are sanctioned, as outlined by the power elites, or institutional regulators in power positions, which represent the objective conditions (social structure) of society that structure social relations and constitute 
the materials by-which embodied consciousness is to be cultivated for the ontological security of the individual. In other words, the general understanding, within a phenomenological structural understanding, is that individual actors or groups (irreducibly situated subjects), lines A and B, are socialized within society its semiotic field or predefined and predetermined lexicons and representations of signification (at the bottom of the diagram) i.e., the field of socialization "and its investment in reproducing and naturalizing the structures of power" through "ideological apparatuses" (at the top of the diagram) controlled by socialized institutional regulators ("As"), which represent an ideological flanking for the economic subjugation running along line "A1." The relation between the two runs this way: societal power operates through a complex relationship between apparatuses (i.e., the law, education, rituals, family etc.) placed on line " $\mathrm{C}$," where in the first instance institutional regulators ("As")-at the top of the line appropriate and manufacture, based on what is already understood, lexicons and representations of signification of individuals in order to consolidate and legitimate itself as a natural "order" and to reproduce individuals as deployable units of that order. So, in the first instance, societal power runs not just through the middle ground of this diagram (A1) but through a complex set of relations happening along line " $\mathrm{C}$;" and since the argument here is that a function (i.e., socialized social actor) at the top of this line is employing those representations created at the bottom of the line in order to make up "knowledge's" that have an ideological function, one can say that the vector of motion along line $\mathrm{C}$ is an upward one, and that this upward motion is part of the whole complex discursive structure whereby society manufactures individuals and thus helps to regulate societal relations. This is the first position.

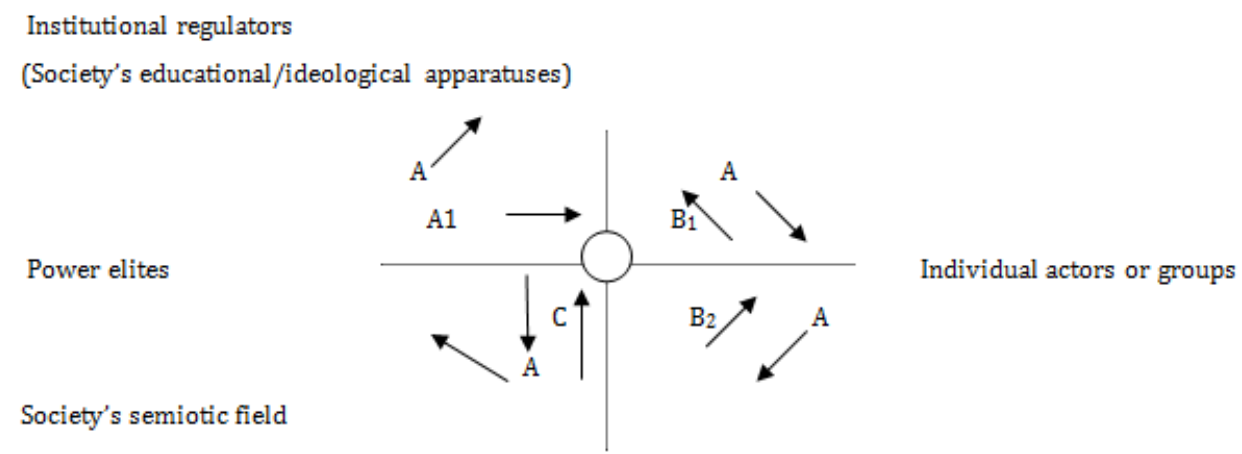

Figure 2 Diagram representing the nature of the relationship-C-between society's semiotic field (bottom of diagram) and the institutional regulators (top of diagram) in phenomenological structuralism.

The second position, as the diagram demonstrates, is the downward movement of societal power, where the institutional regulators of society's apparatuses are understood to be at work in the production of a purely unique and entirely projected idea of the individual, relationally delimited by other fully visible marginalized "alternative" forms of the individual being-in-the-world. The point this movement, which is inextricably tied to the first, is trying to articulate is that society is a product of the working and reworking of reified psychic projections, i.e., ideologies and their apparatuses. Hence, society has to be understood as a structure or system of power relations in which those in power positions attempt to structure, via bodies, language, ideology, ideological apparatuses, and communicative discourse individuals toward an unchangeable unified end associated with the mode of production. This does not mean that there is no agency, for whom or what acts appositionally, in this understanding of the constitution of society, is demonstrated through an understanding of the movements of lines A and B described above.

Essentially, then, in this phenomenological structural understanding, society develops from the interpretive-practical consciousness of those (power elites or social actors in power positions) who maintain control of and integrate its material resource framework. Through this economic and political process, all individual actors ("As" and "Bs"), unless they choose (as a "class-for-itself" under the auspices of their own power elites) to establish their own institutions, are socialized in apparatuses controlled by these social actors, institutional regulators (at the top of the diagram), who employ their representations, the reified symbolic objects that constitute the semiotic field (society) at the bottom of the diagram, in institutions so as to control, guide, and incorporate the ambivalence that lies in the act of interpretation in order to make up and reproduce ideological "knowledge's" that maintain the functioning of the society as a whole. I am arguing that this model, up to this point in the human archaeological research on societal constitution and relations, is a general structure for understanding the multivalent strategies at work in the reproduction and transformation of societies. Furthermore, it resolves the issue of agency, which is problematic when one posits ideology or discourse or psychic processes as constructing human subjects, for who or what acts is clearly demonstrated in the model through the praxis of the structure ("As") and anti-structural elements ("Bs" if they form interpretative communities, " $\mathrm{B}_{2} \mathrm{~s}$ ", which do not seek incorporation or cooptation).

\section{Conclusion}

Essentially, attempting to resolve the structure/agency problematic of the social sciences within structuration theory is tantamount to seeking to account for agency within Louis Althusser's reading of Marxism, which is an anti-humanist account that posits the mode of production and its ideology and ideological apparatuses as the determinant of human social action and subjectification. Whereas structurationists account for agency via the concept of duality, which represents structural reproduction and differentiation associated with the mode of production of a society. Phenomenological structuralism suggests that Being-in-the-world-with-others is the product of an embodied hermeneutic beings' encounter with and interpretation of the social class "language game" (Ludwig Wittgenstein's term) of those who control the economic conditions and distributions (mode of production) of a material resource framework (a la Karl Marx) via the actions of their bodies (practical consciousness), language, ideology, institutions or ideological apparatuses, and communicative discourse, which individual being's consciousness (which is a 
material thing in the brain constituted by recycled subatomic particles of other consciousnesses) encounter via the stances/analytics of their consciousness vis-à-vis their embodiment, the bodies of others, mode of production, language, ideology, and communicative discourse.

Hence within this logic structure and agency are not just a duality as posited by structurationists. They are a duality and a dualism contingent upon the stance/analytic of an individual actor. Social structure is the reification of the material relations of production of a society via the actions of bodies, language, ideology, ideological apparatuses, and communicative discourse (dualism). Within this conception, the origins and nature of human agency or practical consciousness is fourfold

i. The product of the drives of the physical body and brain

ii. Impulses of embodied recycled subatomic particles

iii. Structural reproduction and differentiation according to the rules of conduct which are sanctioned for the material relations (mode) of production

iv. The deferment of meaning in ego-centered linguistic and symbolic communicative discourse-with those in power positions in the ideological apparatuses of the society as the final arbitrators in determining what actions or practical consciousnesses are allowed to (re) organize and reproduce in the material resource framework where the mode of production, language, ideology, ideological apparatuses, and communicative discourse (what Mocombe calls the social class language game) of a social structure is reified. In other words, all four types of praxes are always present and manifested in a social structure to some degree contingent upon the will and desires of the economic social class that controls the material resource framework through the actions of their bodies (practical consciousness), language, communicative discourse, ideology, ideological apparatuses, and social relations of the mode of production. They choose, amidst the class division and differentiating effects of the social relations of the mode of production, what other meaning constitutions and practices are allowed to manifest themselves in the ideological apparatuses of the material resource framework without facing marginalization, domination, or death by other embodied hermeneutic consciousnesses who accept their dominant discourse and discursive practice. Albeit the majority of practical consciousness will be a product of structural reproduction and differentiation given the consolidation of power of those who control the material resource framework wherein a society is ensconced and the threat that power poses to the ontological security of an aggregated individual actor who chooses (or not) either ready-to-hand or present-at-hand to recursively reorganize and reproduce the ideals of the society as their practical consciousness.

\section{Acknowledgements}

None.

\section{Conflict of interest}

The author declares no conflict of interest.

\section{References}

1. Althusser L. Lenin and Philosophy and Other Essays. UK: Monthly Review Press; 2001. p. 1-39.

2. Althusser L, Balibar É. Reading Capital (Ben Brewster, Trans.). UK NLB; $1970.576 \mathrm{p}$.

3. Bourdieu P. Distinction: A Social Critique of the Judgement of Taste (Richard Nice, Trans.). USA: Harvard University Press; 1984. p. 1-632.

4. Bourdieu P. The Forms of Capital. In: JE Richardson, editor. Handbook of Theory and Research for the Sociology of Education. USA: Greenwood Press; 1986.258 p.

5. Bourdieu P. The Logic of Practice (Richard Nice, Trans). USA: Stanford University Press; 1990.340 p.

6. Habermas J. The Theory of Communicative Action: Reason and the Rationalization of Society (Volume 1, Thomas McCarthy, Trans.). USA: Beacon Press; 1984. p. 1-562.

7. Habermas J. The Theory of Communicative Action: Lifeworld and System: A Critique of Functionalist Reason (Volume 2, Thomas McCarthy, Trans.). USA: Beacon Press; 1987. p. 1-463.

8. Giddens A. The Constitution of Society: Outline of the Theory of Structuration. USA: Polity Press; 1984. p. 1-16.

9. Giddens A. Consequences of Modernity. UK: Polity Press; 1990. 188 p.

10. Sahlins M. Culture and Practical Reason. USA: University of Chicago Press; 1976. $259 \mathrm{p}$.

11. Sahlins M. The Apotheosis of Captain Cook. In: Izard M, Smith P, editors. Between Belief and Transgression. USA: University of Chicago Press; 1982. $102 \mathrm{p}$.

12. Sahlins M. Islands of History. USA: University of Chicago Press; 1985. $200 \mathrm{p}$.

13. Sahlins M. Captain Cook at Hawaii. The Journal of the Polynesian Society. 1989;98(4):371-423.

14. Sahlins M. The Political Economy of Grandeur in Hawaii from 1810 to 1830 . In: Ohnuki Tierney E, editor. Culture through Time: Anthropological Approaches. USA: Stanford University Press; 1990. 56 p.

15. Sahlins M. How "Natives" Think: About Captain Cook, For Example. USA: University of Chicago Press; 1995. 328 p.

16. Sahlins M. Historical Metaphors and Mythical Realities. USA: University of Michigan Press; 1995. 18 p.

17. Wittgenstein L. Philosophical Investigations (GEM Anscombe Trans.). USA: Blackwell Publishers Ltd; 1953. 129 p.

18. Crothers C. Technical Advances in General Sociological Theory: The Potential Contribution of Post-Structurationist Sociology. Perspectives. 2003;26(3):3-6.

19. Ortner S. Theory in Anthropology since the Sixties. Comparative Studies in Society and History. 1984;26(1):126-166. 